воспользоваться патентом (п. 2 ст. 346.43 НК РФ); увеличены доступные размеры площадей торгового зала для общепита (п. 6 ст. 346.43 НК РФ); компаниям на патенте разрешили уменьшить налоговую ставку на размер страхового взноса (п. 1.2 ст. 346.51)) [7].

Проблемным местом модернизации существующей налоговой системы является налогообложение. Решения имеющихся вопросов можно добиться двумя способами. Во-первых, необходимо продолжать постепенно снижать общую налоговую нагрузку на коммерческие структуры и довести их до среднеевропейского уровня. Во-вторых, поскольку теневой оборот по-прежнему очень высок, необходимо усилить налоговую дисциплину. Например, почти половина зарегистрированных организаций сдают нулевые балансы. Среди них есть официально существующие компании, которые неэффективны, но большинство компаний скрывают прибыль и не платят налоги.

Совершенствование налоговой системы России связано с широким внедрением современных IT-технологий, позволяющих сократить время обработки большого количества отчетов и выполнения различных расчетов. «Безбумажный» обмен информацией позволяет значительно снизить трудозатраты, повысить его эффективность и сократить количество персонала. При этом следует минимизировать угрозу раскрытия информации о налогоплательщиках.

Таким образом, с помощью эффективной налоговой политики мы добьёмся решения проблем пополнения государственного бюджета, а также решение проблем для обеспечения социального развития и развития страны в целом. Решение внутренних проблем России является предпосылкой ее успешной интеграции в глобализированную мировую экономику. На сегодняшний день не реализована возможность налоговой системы решать все государственные проблемы, что побуждает потребность в дальнейшей модернизации налоговой системы Российской Федерации.

$$
* * *
$$

1. Рощупкина В. В. Современные тенденции модернизации бюджетно-налоговой системы региона / В. В. Рощупкина // Финансовая аналитика: проблемы и решения. - 2012. -№ 48. - С.31-38.

2. Постановление Конституционного Суда РФ от 21 марта 1997 г. «О проверке конституционности положений абзаца второго п. 2 ст. 18 и ст. 20 Закона Российской Федерации от 27 декабря 1991 г. «Об основах налоговой системы в Российской Федерации» // Российская газета от 1 апреля 1997 г.

3. Алексахин А. С. Налоговая политика в реализации качественного содержания социальной политики / А. С. Алексахин // Аудит и финансовый анализ. - 2012. - N 2. - С.8-13.

4. Агузарова Ф. С. Роль имущественных платежей физических лиц в налоговом потенциале (на примере РСО-Алания)//Налоговая политика и практика. - 2012.- №3-1. С.38-40.

5. Мишустин М. В. Совершенствование инструментов налогового администрирования по обеспечению стабильных доходов государственного бюджета. Экономика. Налоги. Право, 2014, № 4, C. 4-8.

6. https://echo.msk.ru/news/2848392-echo.html

7. Налоговый кодекс Российской Федерации (НК РФ). Часть вторая

\title{
Стрыгина C.B. \\ Национальное самосознание как необходимое условие национальной безопасности страны
}

Саратовский национальный исследовательский государственный университет им.

Н.Г. Чернышевского

(Россия, Саратов)

doi: $10.18411 / \mathrm{lj}-06-2021-292$

\section{Аннотация}

В статье рассматривается современное понятие феномена национального самосознания в связи с обеспечением национальной безопасности страны. Обосновывается идея, что российский народ выступает как сформировавшаяся 
гражданская нация. Говорится о значении воспитания силовых структур и вооруженных сил на основе национальных героических традиций. Подчеркивается, что развитое национальное гражданское сознание означает одновременно развитое этническое самосознание.

Ключевые слова: национальная безопасность, гражданская идентичность, самосознание, этнокультурное многообразие, разрешение конфликтов, национальная гвардия.

\section{Abstract}

The article examines the modern concept of the phenomenon of national identity in connection with ensuring the national security of the country. The idea is substantiated that the Russian people act as a formed civil nation. The importance of educating the power structures and armed forces on the basis of national heroic traditions is emphasized. It is emphasized that the Developed national civic consciousness means at the same time the developed ethnic identity.

Keywords: national security, civic identity, self-awareness, ethnocultural diversity, conflict resolution, national guard.

Необходимым условием существования и развития современного цивилизованного государства является развитое национальное самосознание, являющееся одним из оснований обеспечения безопасности страны.

При этом нужно подчеркнуть, что понятие национальное самосознание в полиэтническом государстве, которым является Россия, в настоящее время выступает как синоним гражданского самосознания (или гражданской идентичности). Это связано с тем, что Российская Федерация —многонациональная страна с единой хозяйственной системой и общими идеологическими и культурными ценностями.

«Стратегия государственной национальной политики Российской Федерации на период до 2025 года» к одной из задач в сфере национальной безопасности страны относит укрепление гражданского самосознания [1].

Национальное самосознание - это единство составляющих его бытия: национального (единичного, своего) и общечеловеческого (общего, иного, другого). И сегодняшнее представление о национальной идентичности являет собой феномен принадлежности в первую очередь к государству и всему российскому народу, как сформировавшемуся единому уникальному образованию со множеством наций и народностей. При этом, российский народ выступает как сформировавшаяся гражданская нация [2, с.5].

Значимым элементом России является ее этнокультурное многообразие. Как пишет Т.В. Ромашкин: «Российская идентичность может рассматриваться в контексте диалога цивилизаций и универсализма культурных норм и ценностей» [3, с.56]. Можно выделить четыре составляющих формирования национальной идентичности: осмысление истории своего этноса; оценка его современного положения; оценка перспектив развития; и одновременно с этим понимание этих составляющих в неразрывном единстве со всей страной.

Для обеспечения национальной безопасности страны и общества, непреходящее значение имеет формирование национального самосознания на основе современных гуманистических мировоззренческих императив, которые закладывают как духовную, так и материальную основу сохранности государства. Сформированная гуманистическая составляющая национального государства способна стать платформой, на основе которой выстраиваются действия различных официальных сил, действующих от имени государства в ликвидации мирным путем как внутренних, так и внешних конфликтов. Это способствует выстраиванию межкультурного и межцивилизованного диалога. 
«Многовекторность российской внешней политики, уважение к разнообразию мира, бережное отношение к традиционным ценностям своей страны и других народов лежат в основе уважения к суверенитету, праву нации на выбор своего пути, международному праву в целом...» - пишет политический деятель страны, дипломат Фарит Мубаракшевич Мухаметшин [4].

Развитое национальное гражданское сознание означает одновременно развитое этническое самосознание, важной стороной которого является осознание людьми своей индивидуальности, что они принадлежат именно к этой, а не к другой национальноэтнической и социально-политической общности-нации. Это проявляется в таких понятиях как: «нация», «Я - другой», «культурное многообразие», «диалог культур» и т.д.

Проблема детерминации национального самосознания приобретает особую значимость в связи с происходящими современными этнокультурными процессами. При этом нужно подчеркнуть, что оно выступает как важный источник консолидации граждан в переломные для социума моменты, когда возникают новые формы его выражения, усиливается его роль в идентификационных процессах, происходящих в обществе.

При этом в цивилизованном государстве национальная идентичность должна быть основана на признании «Другого» при определении «я - Другой». Поэтому необходимо осознавать совместное существование разных этносов на основе взаимопомощи и сотрудничества. В связи с этим французский философ Жан - Поль Сартр пишет: «как раз в своем сущностном бытии я зависим от сущностного бытия другого, и вместо того чтобы противополагать мое бытие для меня моему бытию для другого, бытие-для-другого появляется как необходимое условие моего бытия для меня» [5, С. 246].

Уровень осознания того, что каждая национальность имеет свои особенности, которые необходимо уважать, формируется при условии наличия собственной идентичности, национального самоуважения, означающее, что национальное самосознание является единством общественного и индивидуального, социальноклассового и национального, которое объективизируется в межличностных отношениях.

Преобразования, происходящие сегодня в России, затрагивают все сферы общества, в том числе силовые структуры и вооруженные силы, поэтому так необходимо, чтобы составляющей военно - патриотического воспитания стало национальное направление, порождающее чувство патриотизма и гордости у личного состава за выполнение своей миссии. В таком случае происходит осознание идеи, во имя которой проявляется готовность к достойному служению Отечеству, формирование нравственных, профессионально-этических норм поведения, качеств воинской чести, ответственности и коллективизма.

Культурно-историческое содержание воспитания военнослужащих на национальных героических традициях означает обращение к самым значительным страницам истории своей нации, воспитание уважения к своим предкам, культуре народа в тесной связи с общей истории и традициям всей страны, что порождает чувство любви к Родине.

Указанные качества играют большую роль в выполнении задач вооруженными силами страны. Поэтому неоценимое значение имеет здесь национально патриотическое воспитание, когда каждый военнослужащий осознает себя и представителем страны, и представителем определенного этноса. Это рождает способность не просто к защите интересов государства, но и к выполнению наилучшим образом задач, поставленных перед военнослужащими на основе принципах Конституции Российской Федерации. 
Особо следует выделить в обеспечении национальной безопасности страны роль национальной гвардии Российской Федерации, созданной в апреле 2016 года по указу Президента страны.

В Федеральном законе от 03.07.2016 N 226-Ф3 «О войсках национальной гвардии Российской Федерации», перед Росгвардией поставлены задачи, решение которых направлено на реализацию ее предназначения по обеспечению государственной и общественной безопасности, защиты прав и свобод человека и гражданина [6].

Нужно отметить, что осуществление этих задач предполагает в ряде случаев знание национальных традиций населения. Это необходимо, например, где принимаются меры для ликвидации национальных или религиозных конфликтов. В противном случае это может привести к непредвиденным последствиям и даже необоснованным жертвам с обеих сторон, результатом чего будет снижение легитимности власти.

В таких конфликтах можно наблюдать деструктивное проявление национального чувства, которое выражает эмоциональное отношение к собственной этнической действительности, ее интересам, ценностям и форме жизни, а также характер межнациональных отношений. Эти чувства могут иметь как позитивный, так и негативный оттенок.

Кроме того, задачи национальной гвардии усложняются возрастающим количеством эмигрантов, которым не всегда понятны традиции страны пребывания, поэтому это может проявляться в противостоянии, враждебности при общении, как с населением, так и с представителями власти.

Вместе с тем, в «Стратегии государственной национальной политики Российской Федерации» одним из вызовов национальной безопасности определены непреодоленные последствия межэтнических и этнических конфликтов и противоречий, возникших в субъектах федерации [1]. Преодоление этих вызовов может быть в случае, если самим участникам их ликвидации свойственно высокое национальное самосознание.

Одним из главных направлений стратегии государственной и общественной безопасности являются сохранение гражданского мира, политической и социальной стабильности в обществе, а главной целью использования силовых структур является скорейшая нормализация обстановки, устранение угрозы безопасности граждан, решение конфликта политическими средствами и восстановление законности и правопорядка.

Национальное самосознание - это то, что связывает нацию в целое духовное и социокультурное пространство. Поэтому его формирование у тех, кто призван профессионально защищать интересы родины, имеет первостепенную важность.

Русский ученый - философ Николай Бердяев писал: «Охранить отечество, отстоять его честь и возвеличить его могут лишь те люди, у которых в душе сохранилась народная святыня и не порвалась связь с народным целым» [7].

В основе национальной идентичности лежат исторические культурные ценности, которые являются духовной основой общества. Американский политик, автор трудов о сохранении традиционных общественных ценностей как основе консолидации нации, Патрик Джозеф Бьюкенен писал: «Уничтожьте записи о прошлом народа, оставьте его жить в невежестве относительно деяний предков - и опустевшие сосуды душ легко будет заполнить новой историей, как это описано в «1984». Развенчайте народных героев - и вы деморализуете целый народ» [8].

Значительной по важности стороной в развитии национальной идентичности является соотношение этнических, национальных и общечеловеческих ценностей. Представление о себе и о «других» создает поле межкультурной коммуникации.

Политика национальной безопасности Российской Федерации тесно связана со стратегией демократического развития страны на основе принципов гуманизма, 
является ее неотъемлемой частью и одновременно условием ее воплощения в жизнь, а сформированная национальная идентичность способствует консолидации гражданского общества.

$$
* * *
$$

1. Стратегия государственной национальной политики Российской Федерации на период до 2025 года (ред. от 06. 12. 2018 года). URL: http:/pravo.gov.ru/proxy/ips/?docbody=\&nd=102161949 (дата обращения 20.04.2021).

2. Тишков В.А. Российский народ: история и смысл национального самосознания. Институт этнологии и антропологии им. Н.Н. Миклухо- Маклая РАН. - М.: Наука, 2013. - 649 с.

3. Ромашкин Т.В. Межэтническое взаимодействие в контексте российской идентичности // Актуальные проблемы гуманитарных и общественных наук. 2016. № 9-10 (66-67) - С.55-61

4. Мухаметшин Фарит Новый гуманизм как мировоззренческая основа культуры мира // Международная жизнь. 2012. №1. URL: https://interaffairs.ru/jauthor/material/600 (дата обращения 20.04.2021).

5. Сартр Ж. П. Бытие и ничто: Опыт феноменологической онтологии / Сартр Ж. П. M., 2000. URL: http://yanko.lib.ru/books/philosoph/sartre=butie_i_nichto=ann.htm\#_Toc130721406 (дата обращения 20.04.2021).

6. О войсках национальной гвардии Российской Федерации. Федеральный закон N $226-\Phi 3$ от 03.07.2016 (ред. от 31.07.2020). URL: www.pravo.gov.ru (дата обращения 20.04.2021).

7. Бердяев Н.А. О русском национальном сознании. URL: http:/www.spasi.ru/biblt/berd6.htm (дата обращения 20.04.2021).

8. Бьюкенен Патрик Дж. Смерть Запада / Бьюкенен Патрик Дж. URL: https://azbyka.ru/fiction/smertzapada/ (дата обращения 20.04.2021).

\section{Упоров И.В., Долгов А.А. \\ Институт государственной (гражданской) службы в России (период до 1725 года): истоки и развитие}

Краснодарский университет МВД России (Россия, Краснодар)

doi: 10.18411/lj-06-2021-293

\section{Аннотация}

Рассматриваются основные тенденции в формировании и развитии института государственной гражданской службы в истории России в период до окончания правления Петра I. Анализируются нормы правовых актов, научные труды по заявленной теме. Отмечается, что в Древнерусском государстве на первый план выходила военная служба, и такой приоритет сохранялся довольно долго. Постоянные должности гражданской службы (в приказах, земских учреждениях и др.) стали создаваться только в Московском государстве, тогда же они стали закрепляться в законодательстве (например, Соборное уложение 1649 г.), но без определенной системы. В известных указах Петра I этот недостаток был преодолен, и с того времени институт гражданской службы стал непременным атрибутом государственного аппарата.

Ключевые слова: государство, гражданская служба, приказы, должности, указы, полномочия, общество, закон.

\section{Abstract}

The main tendencies in the formation and development of the institution of the state civil service in the history of Russia in the period before the end of the reign of Peter I are considered. The norms of legal acts, scientific works on the stated topic are analyzed. It is noted that military service came to the fore in the Old Russian state, and this priority remained for quite a long time. Permanent positions of the civil service (in orders, zemstvo offices, etc.) began to be created only in the Moscow state, at the same time they began to be 